\title{
Sumak Kawsay: Ecuador Builds a New Health Paradigm
}

\section{César Hermida MD MS}

The new Ecuadoran Constitution, approved in 2008, represents a watershed in the history of the nation. It articulates new relationships with the public-at-large as actors in social construction-the millennial cultures that make up this nation-and with the concept and right accorded to health itself.

The Constitution was the result of a National Constituent Assembly, mandated by $86 \%$ of voters in 2007 . Assembly headquarters received some 70,000 people and heard from many more in visits throughout the country, finally processing 1600 proposals.[1] Indigenous and other progressive organizations advanced innovative ideas that the new Constitution introduced as pioneering paradigms, particularly in health and health care.

The ideas thus adopted, challenge the conventional Western concept of "development" centered on economic growth, unfettered consumption and profit, which have resulted in inequities and injustice in our country, and marginalization of entire groups without protection or security. The new framing on the other hand seeks a harmonic relationship among human beings and with Pacha Mama (Mother Earth), as well as recognition of the Ecuadoran nation as "intercultural" and "pluri-national," establishing public policies that embrace ancestral wisdom and practices.

The Constitution's Preamble offers a preview of Articles related to health when it states: "Appealing to the wisdom of all the cultures that enrich us....as heirs to social struggles of liberation from all forms of domination and colonialism...we have decided to construct a new way of living together as citizens, in diversity and harmony with nature, to achieve 'common wellbeing,' sumak kawsay" (from the Quechua, sumak, good, beautiful, pleasurable; and kawsay, collective life).

Article 32 characterizes health as "a right guaranteed by the state, whose fulfillment is linked to the exercise of other rights... (to) water, food, education, physical exercise, work, social security, a healthy environment and others that ensure common wellbeing. The State will guarantee the right to health through economic, social, cultural, educational and environmental policies; permanent and opportune access, with no exclusions, to programs, actions and services related to promotion and comprehensive attention to health in general, and to sexual and reproductive health. Health services provision will be guided by principles of equity, universality, solidarity, interculturality, quality, efficiency, efficacy, precaution and bioethics, with a gender and generational approach."

Thus, the concepts of health, disease and health care ultimately refer to quality of life-sustained by fulfilling objective and subjective human needs-and to the responsibility of the state to guarantee the right to health. In Eurocentric, Western, capitalist models, biological concepts of health and disease dominate medicine, preventing their health systems from assuming an integrated bio-psycho-social approach. The context for health care provision is essentially a mercantile one, in which humanism becomes increasingly disregarded over time. Despite this, by the end of the $20^{\text {th }}$ century, "new" conceptions of health and life were discovered —or actually recovered. Latent for
500 years in the hands of our native ancestors, these concepts now flourish in the new national paradigm of sumak kawsay.

Article 358 of the new Constitution describes the national health system's aims as: "development, protection and recovery of the capacities and potential for a healthy, integral life for the individual as well as the collective, recognizing social and cultural diversity..." Incorporating this new understanding of life and right to health requires transforming the old health system in the following ways:

- The limited view of health that separated body and soul is replaced by an approach that reunifies them, applying a holistic concept of health for individuals, groups and society, with responsibility for health and social services lying with the state.

- Medicine historically separated manual from intellectual labor, incorporating science and technology to cure disease. The new focus puts medicine and medical technology at the service of health promotion, not just curing disease.

- Health services that had concentrated modern medicine in cities are extended, on the basis of ethics and the principle of universal coverage, to rural areas, broadening the concept of health and wellbeing.

- A medical paradigm brought from European (white) cultures is transformed, searching for a genuinely mestizo paradigm based on values emanating from 'white' as well as ancestral indigenous and Afro-descendent cultures, the last two heretofore representing populations both marginalized and poor.

...a genuinely mestizo
paradigm based on values
emanating from 'white' as
well as ancestral indigenous
and Afro-descendent cultures.

The changes under way-providing for inclusion of science, technology and innovation, in addition to ancestral wisdom-are the result of a lengthy, extensive and dynamic process of public political debate that continues today. In the National Plan (2009-2014) therefore, the term "development" has been replaced by "common wellbeing;" such transformative concepts are now the subject of postgraduate courses at university; and discussion flourishes within state agencies and civil society alike on the "keys to reconstructing common wellbeing."[2]

Interpreting the Constitution through the application of an official policy of universal and free health care offers another example of advances towards human equity: 500 years after first contact with Europe, a new understanding of common wellbeing-of health and life-is becoming clear in word and deed. Its application by government at all levels is the challenge ahead. -1 -

1. Pérez O, editor. La Constitución de Montecristi: Un Sueño Colectivo; El camino hacia el buen vivir, Quito: Asamblea Nacional; 2010 Jul. Spanish.

2. Fernández G, Calderón LF, Cachiguango LE, Castañeda A. Salud, interculturalidad y derechos, claves para la reconstrucción del Sumak Kawsay-Buen vivir. Quito: 2010. Ministerio de Salud Pública (EC). 408 p. Spanish.

Submitted: October 10, 2010

Approved for publication: June 30, 2011

Disclosures: None 